\title{
今日の話題
}

為的に傷をつけたときの病害抵抗性を調べたところ, 傷 をつけたイネは，傷をつけない対照イネとまったく同じ ような病気の進行度合いを見せたことから，物理的な傷 害がこの抵抗性をひき起こす要因ではないことが明らか となった ${ }^{(2,4)}$.

これらの結果を受けて，本抵抗性の誘導には，生物間 の相互作用が重要であることが明らかとなった。では, この間接誘導抵抗性はイネとセジロウンカの組み合わせ のときのみに誘導されるものなのだろうか. イネを加害 し, 同じような吸汁様式を示すウンカは他にも存在し, これらウンカ類とイネの組み合わせのときでもこの抵抗 性が誘導される可能性はあると十分考えられる. そこ で，セジロウンカの代わりにトビイロウンカを用いて同 じような実験を行なったところ, 大変興味深いことに,

トビイロウンカの加害を受けたイネは病気に強くならな かった.このことは, セジロウンカの加害を受けたイネ とトビイロウンカの加害を受けたイネは, 植物体内でそ れぞれ違った反応を示すことを示しており, その反応の 差の結果がその後の病気に対する抵抗性に影響すること が推察された。 そこで, セジロウンカの加害を受けたイ ネと, トビイロウンカの加害を受けたイネの反応の差を 遺伝子レベルで解析した結果, セジロウンカの加害を受 けたイネは, 抵抗性関連遺伝子や, $(E)-2$-ヘキセナール (青葉アルデヒド) という植物の青臭さ成分（緑のかお り）を合成するのに必須な遺伝子を強く発現し，青葉ア ルデヒドを多く蓄積することがわかった ${ }^{(2)}$. 青葉アルデ ヒドは抗菌活性を有し白葉枯病菌の成長を抑制するこ と, また青葉アルデヒドに曝露されたイネでは白葉枯病 の抵抗性が高まることも明らかとなった ${ }^{(2)}$. 遺伝子組換 え技術によって青葉アルデヒド合成酵素遺伝子を過剰に 発現させたイネでも白葉枯病の抵抗性が高まることを確 認した ${ }^{(2)}$.これらの結果より，セジロウンカの加害で大
量に蓄積される青葉アルデヒドが，上記の古い諺の由来 を解明する一つの物質的証拠であるといえる.

一方，セジロウンカの「何」がシグナルとなって，イ ネに「緑のかおり」の蓄積や抵抗性遺伝子発現を誘導さ せるかを明らかにすることは非常に重要であると考えら れる。上記のように，セジロウンカの吸汁行動を模した 人工的な刺激ではこの間接誘導抵抗性が付与されないこ とから，セジロウンカの吸汁時に口からイネ体内に放出 される唾液成分の中に抵抗性を誘導させる物質が存在す ると筆者らは考え，抵抗性を誘導しないトビイロウンカ に存在せずにセジロウンカに存在する遺伝子産物や物質 の同定を試みている.

ここに述べた研究は，これまで別々に研究が進んでき た「植物一病原体相互作用」と「植物一食植性昆虫相互作 用」を「植物一昆虫一病原体」の三者間の相互作用として 捉えなおす必要性を我々に提示するものであり，生物間 の相互作用の新たな研究領域となりつつある。またこの ような研究は, 将来的には, 安全安心な農業生産にもつ ながるものと期待している，本研究によって，緑のかお りの生態系における機能の一つは，害虫や病気に対する 抵抗性であることが実証できた。 また，食害や病気の感 染というストレスに対する緑のかおりの誘導的な生産を 増強させたこと屯注目すべき点であると考えられる．緑 のかおりの生合成経路の遺伝的改変は，植物のもつ自然 な防衛能力を強化しようというものであり，これまでの 研究とはまったく異なるアプローチでの遺伝子組換え作 物の作出が期待される.

1) H. Kanno \& Y. Fujita:Entomol. Exp. Appl., 107, 155 (2003).

2) K. Gomi et al. : Plant J., 61, 46 (2010).

3) M. Satoh et al. : Jpn. J. Appl. Entomol. Zool., 49, 105 (2005).

4) H. Kanno et al. : Appl. Entomol. Zool., 40, 91 (2005).

(五味剣二, 香川大学農学部)

\section{猛暑の年は酒粕が多くなる？ 気象データによる清酒醀造用原料米の性質予测}

清酒醸造では, 香味の調和を図るため, ご飯で食べる お米に比べて高度に精米された（立米を外側から削っ た）国産米が原料に使われる。そのため, 原料米の経費 が製造コストの大半を占め, 品質を保ちつつ原料米の利 用率を上げることが重要である。清酒の醸造工程は他の
酒類と比べ複雑で, 麹菌の酵素による米の溶解・糖化と 酵母によるアルコール発酵が並行して進む“並行複発酵 方式”で行なわれる。原料米の溶解の程度が原料利用率 を左右し結果として味の濃淡に大きく影響するため, 原 料米の溶解をいかに制御するかが，アルコール発酵とと 
もに工程管理の重要なポイントである.

原料米の溶解には，米の性質が大きく影響している. 米の性質は，同じ品種であっても生産年や生産地の気象 条件によって左右され, 醸造工程や清酒の品質へ影響す ることが経験的に知られている. 米の性質を把握するた め酒造期前に全国的に分析が行なわれるが，手間がかか るため分析点数は限られている。したがって, 酒造現場 のほとんどでは，酒造初期においては米の性質がよくわ からないまま仕込んでみて様子を見ながらもろみの管理 を行なっている.つまり, 清酒を仕込んでみてはじめて 米の性質を知ることになるのである.

原料米の溶解性がどのような要因で決まるかは, 清酒 製造業者によって重大な関心事であるため, その要因解 明に向けて古くから研究が行なわれてきた，近年，米の 大部分を占めるデンプンに着目して行なわれた研究か ら, イネ登熟期（出穂して種子が成長してゆく時期）の 気温がデンプンの組成や構造を変化させた結果, 米の溶 解性に大きく影響することが明らかにされた.さらに気 象データの利用により米の溶解性が予測できる可能性が 示された.ここではこれらの成果を紹介したい.

米の成分の大半を占めるデンプンは，ブドウ糖が直鎖 状につながったアミロースとブドウ糖の鎖が房状に枝分 かれしたアミロペクチンがうるち米では約 $1: 4$ の比率 で構成されている (図 1). デンプンは巨大分子なので解 析が難しく, 高次構造や生合成機構について不明な点が 多かったが, 近年, 分析手法の発達で, 微細構造やデン プン熱特性との関係, 生合成機構の研究が進展した. そ こでデンプンに着目し，その組成・分子構造と蒸米の酵 素消化性（米の溶解性をみる分析項目）との関係につい

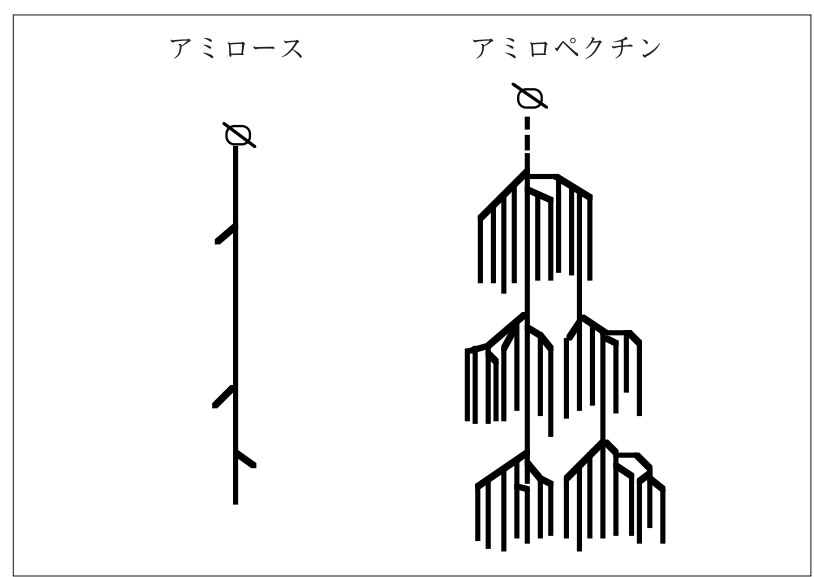

図 1 ・デンプンを構成する成分
て解析が行なわれた ${ }^{(1,2)}$. まず，デンプンの組成や構造が 異なる変異体試料などを用いて, デンプンの分子構造と 蒸米の酵素消化性との関係について調べたところ，原料 米のデンプン中のアミロース含量とアミロペクチンの側 鎖構造（枝の長さ）が蒸米中のデンプンの老化と関連が あり，これが蒸米の酵素消化性に大きく影響しているこ とが見いだされた(1). すなわち，アミロース含量が少な い米ほど，またアミロペクチンの側鎖が短い（短い鎖の 割合が多い) ほよ゙，デンプンの老化が遅く蒸米が硬くな りにくいため，消化されやすいことが明らかになった。 さらに，清酒醸造に用いられる品種ではアミロース含量 にあまり差がないためアミロース含量が消化に及ぼす影 響は少なく，蒸米の酵素消化性はアミロペクチンの側鎖 構造に従うことがわかった ${ }^{(2)}$.

また, 人工気象室を用いてイネ登熟期気温（イネ出穂 後の気温）が米の酒造適性へ及ぼす影響について研究が 行なわれた ${ }^{(3,4)}$. その結果, イネ登熟期の温度が高いと, アミロペクチンの側鎖（枝）が長くなり，デンプンの老 化が速く（蒸したお米が速く硬くなり）, 消化されにくい （米の溶解が悪く，利用率が低い）ものとなっていた．低 温のときはアミロペクチンの枝が短く, 老化がゆっくり 進むため消化されやすいものとなっていた，イネ登熟期 気温のデンプン分子構造への影響は 1980 年代に見いだ され(5), 近年ではデンプン生合成系遺伝子レベルでの解 析も行なわれている(6) が，イネ登熟期の気温は清酒醸造 における原料米の溶解性にまで影響することが明らかに された。これらは，天候の良い年の米は硬くむろみで溶 けにくく，逆に冷夏の年は溶けやすいという過去の清酒 醸造における経験則とぴったりと一致しており，イネの 栽培時の気象条件で原料米の酒造適性が予測できる可能 性が見いだされた.

さらに，9 年間の統計資料の解析から，清酒醸造にお ける全国加重平均の粕歩合（原料の白米に対する搾り終 えた後の酒粕の割合）はイネの登熟期の気温と正の高い 相関性を示すことが明らかされた (7). すなわち，実際の 酒造現場においても，イネの登熟期の気温が高い年は米 の溶解性が悪く酒粕が多くなっていた。このことから も，イネ登熟期の気温が米のデンプンの性質に影響を及 ぼした結果，清酒醸造での米の溶解性に影響した可能性 が考えられた。

そこで，イネ登熟期の気象データの明らかな日本各地 から収集された試料を用いて，気象データとデンプン特 


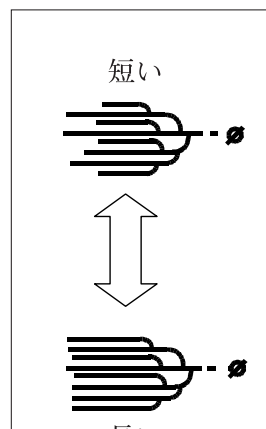

長い

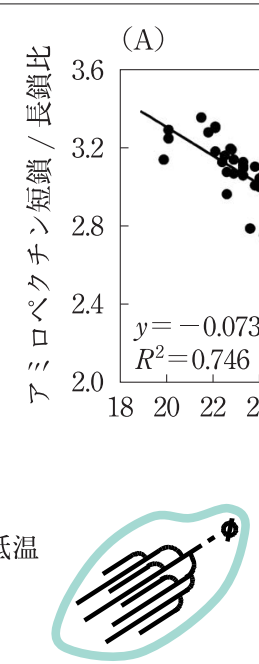

アミロペクチン側鎖が短い

$\rightarrow$ 老化しにくい

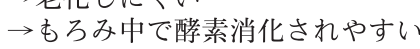

(B)

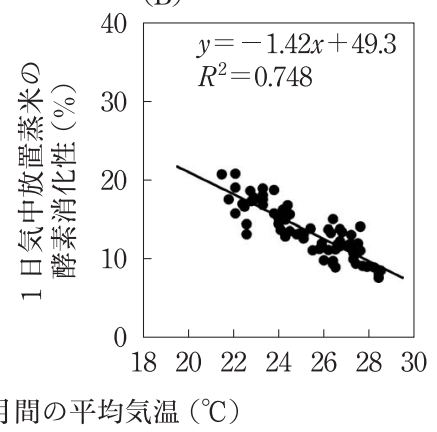

高温

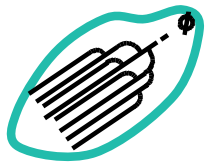

アミロペクチン側鎖が長い

$\rightarrow$ 老化しやすい

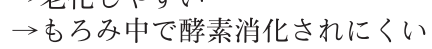

図 2・イネ登熟期気温による清酒 もろみ中の米の溶解性の予測
性および蒸米の酵素消化性との関係を解析し, 気象デー 夕により蒸米の酵素消化性（米の溶解性）を予測できる かが検討された ${ }^{(8)}$. その結果, イネ登熟期の平均気温は, 日照時間や気温日格差よりデンプンの性質（アミロペク チンの側鎖構造）および蒸米の酵素消化性と高い相関関 係を示すことが明らかになった（図 2).この結果は人工 気象室を用いた結果 ${ }^{(3,4)}$ と一致しており, イネ登熟期の 気温によりかなり高い精度で原料米の溶解性に関する酒 造適性を予測できる可能性が示唆された。 産地近隣の気 象データはアメダス (AMeDAS) から簡単に入手できる ため, 酒造前に容易に米質を把握した上で清酒製造がで きるようになり，原料米の利用率や清酒の品質向上に大 きく貢献できると考えられる.

清酒醸造の製造責任者である杜氏さん方がよく口にさ れる中に『酒造りは毎年が一年生』という言葉がある. その言葉の中には, 『年によって米の性質が異なるため 毎年一から酒造りをスタートするような感覚になる』と いった意味合いも含まれるように思われる。 今回紹介し た研究によって, これまで実際に仕込んでみてからしか 対応できなかった工程管理が, 米の性質を知ることによ り事前に対応可能になるものと期待される。これから
は，杜氏さん方も『毎年一年生』の状態ではなく，重要 なお米の性質をよく知った上で酒造期を迎えることがで きるようになると考えられる。近年，イネの登熟期にあ たる夏から秋にかけて高温になる年が多いため，酒造期 前に米の性質を予測できれば，清酒の品質や原料利用率 の向上に役立つものと思われる. 今後, これらの成果が 酒造現場に適用できるよう, さらなる研究の進展が期待 される。

1) M. Okuda, I. Aramaki, T. Koseki, H. Satoh \& K. Hashizume: Cereal Chem., 82, 361 (2005).

2) M. Okuda, I. Aramaki, T. Koseki, N. Inouchi \& K. Hashizume: Cereal Chem., 83, 143 (2006).

3）小関卓也, 奥田将生, 米原由希, 八田一隆, 岩田 博, 荒 巻 功, 橋爪克己 : 䁔協, 99, 591 (2004).

4) 米原由希, 小関卓也, 奥田将生, 荒巻 功, 橋爪克己：醸 協, 100, 650 (2005).

5) M. Asaoka, K. Okuno, Y. Sugimoto, J. Kawakami \& H. Fuwa : Starch/Stärke., 36, 189 (1984).

6) H. Yamakawa, T. Hirose, M. Kuroda \& T. Yamaguchi Plant Physiol., 144, 258 (2007).

7）橋爪克己，奥田将生：釀協， 103，945 (2008).

8）奥田将生，橋爪克己，沼田美子代，上用みざり，後藤奈美， 三上重明：醸協, 104, 699 (2009).

（奥田将生，（独)酒類総合研究所） 